The half life of antipyrine reflects the metabolic capacity of the hepatocytes and is not influenced by plasma protein binding or hepatic drug delivery rate. Therefore the antipyrine clearance rates in our subjects indicated each individual's capacity to metabolise drugs.

Although a diuretic had been given to the patients with nutritional oedema before the study, some degree of expansion of the extracellular fluid volume remained. Nevertheless, Reidenberg et $a l^{16}$ have shown that the metabolism of antipyrine and tolbutamide is not changed in obese fasting subjects despite significant changes in body water. The prolonged half life seen in patients with nutritional oedema was therefore unlikely to have been due to changes in body water. This view was also supported by the observations that relative volume distribution was similar in all the groups investigated.

These changes in the metabolism of antipyrine in malnourished subjects indicate that in certain conditions drug regimens may have to be changed. A reduction in half life may call for more frequent administration of drugs. On the other hand, if microsomal enzyme activity is impaired, and the half life prolonged, patients may be at a greater risk of accumulating potent drugs.

We thank Dr S G Srikantia, Director of the National Institute of
Nutrition, for his keen interest and helpful discussions. Our thanks are also due to Mr V K Goud, for his technical help.

\section{References}

1 Campbell, T C, and Hayes, J R, Pharmacological Reviews, 1974, 26, 171.

2 Basu, T K, and Dickerson, J W T, Chemical-Biological Interactions, 1974 8, 193

${ }^{3}$ Poskitt, E M E, Proceedings of the Nutrition Society, 1974, 33, 203.

4 Shastri, A K, and Krishnaswamy, K, Clinica Chimica Acta, 1976, 66, 157.

5 Brodie, B B, and Axelrod, J, fournal of Pharmacology and Experimental Therapeutics, 1950, 98, 97.

${ }^{6}$ Brodie, B B, et al, fournal of Biological Chemistry, 1949, 174, 25.

7 Medical Clinics of North America, 1974, 58, 905.

8 Wilkinson, G R, and Schenker, S, Drug Metabolism Reviews, 1975, 4, 139.

9 Vessel, E S, Medical Clinics of North America, 1974, 58, 951.

10 Rosalki, S B, and Rau, D, Clinica Chimica Acta, 1972, 39, 41.

11 Vestel, R E, et al, Clinical Pharmacology and Therapeutics, 1975, 18, 425.

12 Kolmodin, B, et al, Clinical Pharmacology and Therapeutics, 1969, 10, 638.

13 Basu, T K, et al, Nutrition and Metabolism, 1975, 18, 49.

14 Mgbodile, M U K, PhD thesis, Virginia Polytechnic Institute and State University, 1972.

15 Gopalan, C, and Krishnaswamy, K, Progress in Food and Nutrition Sciences, 1975, 1, 207.

${ }^{16}$ Reidenberg, M M, and Vessel, E S, Clinical Pharmacology and Therapeutics, 1975, 17, 650 .

(Accepted 23 December 1976)

\title{
Controlled trial of active immunotherapy in management of stage IIB malignant melanoma
}

\author{
M B McILLMURRAY, M J EMBLETON, W G REEVES, M J S LANGMAN, M DEANE
}

British Medical fournal, 1977, 1, 540-542

\section{Summary}

The prognosis for patients who undergo surgery for stage IIB malignant melanoma is poor. Animal studies have suggested that BCG and tumour cell vaccines given together may provide effective immunotherapy. To assess the effectiveness of this treatment 15 patients with stage IIB malignant melanoma who had had their tumour excised were studied. Seven were treated conservatively, and eight were vaccinated with BCG and autologous irradiated cells. Three vaccinated patients suffered widespread recurrence within three months. All four vaccinated patients who suffered a recurrence within the first year died, while none of the three controls with recurrent disease died. In view of this alarming trend the trial was stopped after a year. BCG and the tumour cells may have enhanced the tumour growth, although

\section{City Hospital, Nottingham NG5 1PB}

M B MCILLMURRAY, MB, MRCP, lecturer, university department of therapeutics

W G REEVES, MB, MRCP, consultant immunologist

M J S LANGMAN, MD, FRCP, professor, university department of therapeutics

M DEANE, FRCs, consultant plastic surgeon

Cancer Research Campaign Laboratories, University of Nottingham M J EMBLETON, PHD, research officer there was no apparent reason for this. The results of uncontrolled or unrandomised trials that have suggested that this treatment is beneficial should be treated with scepticism.

\section{Introduction}

Within two years of operation about three-quarters of all patients with malignant melanoma who have affected regional nodes (stage IIB) will have obvious recurrences and over half will have died. ${ }^{1}$ Results are therefore likely to improve only if some other treatment can be added to excision.

The demonstration of tumour-associated antigens on melanoma cells and of circulating antibodies and cytotoxic lymphocytes directed against them in patients with the disease has suggested that immunotherapy may be useful, ${ }^{2}$ but there have been few good controlled clinical trials of such treatment. Bacillus Calmette-Guérin (BCG) has been included in the treatment of malignant melanoma as a non-specific immunostimulant. Intralesional BCG will often produce tumour regression, ${ }^{4}$ and intradermal $B C G$, given repeatedly, may delay recurrence after surgery ${ }^{5}$ and augment the response to chemotherapy. ${ }^{6}$ In contrast, specific immunotherapy with irradiated tumour cells, while increasing cytotoxic antibody production and the proportion of circulating cytotoxic lymphocytes, has no apparent effect on the outcome in patients with widespread disease. ${ }^{7}$ Nevertheless, animal studies indicate that host resistance to transplantable tumours is enhanced when BCG and tumour cell vaccines are given together as contact immunotherapy provided that the tumour load is small. This suggests 
that such a combination may be a more effective immunostimulant than either given alone. ${ }^{8}$

We report here the results of a small controlled trial to determine the effect of BCG and irradiated tumour cell vaccines on the prognosis of patients with stage IIB malignant melanoma who had first been rendered clinically free of tumour by surgery.

\section{Patients and methods}

Permission for the trial was obtained from the North Nottingham District ethical committee.

Fifteen patients with Stage IIB malignant melanoma were included in the study. Table I shows the site of the primary melanoma, the time interval from treatment of the primary lesion to presentation with recurrence, the extent of lymph node disease at operation, and the skin responses to varidase and purified protein derivative at entry to the study.

TABLE I-Clinical details of patients in the two groups

\begin{tabular}{|c|c|c|c|c|c|}
\hline \multirow{2}{*}{$\begin{array}{l}\text { Case } \\
\text { No }\end{array}$} & \multirow{2}{*}{$\underset{\text { site }}{\text { Primary }}$} & \multirow{2}{*}{$\begin{array}{c}\text { Interval from } \\
\text { treatment of } \\
\text { lesion to } \\
\text { recurrence* } \\
\text { (months) }\end{array}$} & \multicolumn{2}{|c|}{ Skin testing } & \multirow{2}{*}{$\begin{array}{l}\text { No of lymph } \\
\text { nodes affected }\end{array}$} \\
\hline & & & PPD & Varidase & \\
\hline \multicolumn{6}{|c|}{ Conservatively treated patients } \\
\hline $\begin{array}{l}1 \\
2 \\
3 \\
4 \\
5 \\
6 \\
7\end{array}$ & $\begin{array}{c}\text { Trunk } \\
\text { Scapula } \\
\text { Scapula } \\
\text { Leg } \\
\text { Leg } \\
\text { Scapula } \\
\text { Alveolus }\end{array}$ & $\begin{array}{r}24 \\
0 \\
12 \\
19 \\
0 \\
0 \\
5\end{array}$ & $\begin{array}{l}+ \\
+ \\
+ \\
+ \\
+ \\
+\end{array}$ & $\begin{array}{l}+ \\
+ \\
+ \\
+ \\
+ \\
+\end{array}$ & $\begin{array}{r}1 \\
1 \\
1 \\
>4 \\
1 \\
>4 \\
>4\end{array}$ \\
\hline \multicolumn{6}{|c|}{ Vaccinated patients } \\
\hline $\begin{array}{r}8 \\
9 \\
10 \\
11 \\
12 \\
13 \\
14 \\
15\end{array}$ & $\begin{array}{l}\text { Leg } \\
\text { Leg } \\
\text { Arm } \\
\text { Scapula } \\
\text { Scapula } \\
\text { Shoulder } \\
\text { Parotid } \\
\text { Arm }\end{array}$ & $\begin{array}{r}28 \\
36 \\
4 \\
0 \\
11 \\
14 \\
12 \\
0\end{array}$ & $\begin{array}{l}- \\
+ \\
+ \\
+ \\
+ \\
- \\
-\end{array}$ & $\begin{array}{l}- \\
+ \\
+ \\
+ \\
+ \\
+ \\
+ \\
+\end{array}$ & $\begin{array}{r}1 \\
2 \\
>4 \\
>4 \\
1 \\
1 \\
>4 \\
>4\end{array}$ \\
\hline
\end{tabular}

$*_{0}=$ Simultaneous

The primary tumour was treated by wide excision followed by skin grafting. Regional lymph nodes were excised and the patients were then judged to be tumour free after thorough clinical examination and after scans of liver, bone, and brain and radiographs of chest and skeleton were shown to be normal. After the procedure had been explained patients were randomly allocated to either a treatment group, in which they received the vaccine after operation, or a control group, in which they received no further treatment. The vaccine consisted of a mixture of $3 \times 10^{7}$ live BCG (Glaxo) and $5 \times 10^{7}$ autologous irradiated tumour cells. It was given intradermally on the 14th day after operation into each upper arm, each thigh, and just below the umbilicus.

There were eight patients in the vaccinated group (two women and six men) and seven patients in the control group (two women and five men), their mean ages being $49 \cdot 8$ and $42 \cdot 0$ respectively (table I).

On the 14th day after operation and at monthly intervals for three months and at six and 12 months patients were assessed clinically for evidence of recurrent disease. In those who remained tumour-free skin tests with varidase and purified protein derivative (PPD ; 1/10 000, 1/1000, 1/100 dilutions) were performed, and blood was taken for routine testing. The immunological investigations performed were: total and differential white cell count; lymphocyte transformation studies in response to pokeweed mitogen, concanavalin $\mathrm{A}$, and phytohaemagglutinin, both with and without autologous serum and at high and low concentrations; estimation of immunoglobulin and complement levels; and measurement of leucocyte migration inhibition to melanoma extract and cell-mediated and complementdependent cytotoxicity against cultured melanoma target cells (the results of these studies are to be published). Chest radiographs were taken every six months and scans were performed every year or more often if there was clinical indication.

Vaccinated patients were asked to record their temperature daily for 14 days, or longer if they had a persistent fever.

\section{Results}

Table II shows the recurrence and death rates in vaccinated and unvaccinated patients. Three patients (one vaccinated and two controls) were followed for less than a year, and this accounts for the reduced numbers in each group at 12 months. Three of the four recurrences in the vaccinated group occurred early and were strikingly widespread: they affected bone, brain, lung, and viscera. All four patients died rapidly. In contrast, recurrent disease in the control group occurred locally at the operation site in two patients and both remained well four months after simple excision of the metastases. The third patient, who had cerebral metastases only, remained alive and well three months after cytotoxic therapy with dacarbazine and dexamethasone.

TABLE II-Recurrence and death rates in the two groups of patients. Results are numbers of patients with recurrence (or who died) out of number studied

\begin{tabular}{|c|c|c|c|c|}
\hline & \multicolumn{2}{|c|}{ Recurrence rate } & \multicolumn{2}{|c|}{ Death rate } \\
\hline & $\begin{array}{l}\text { Vaccinated } \\
\text { patients }\end{array}$ & Controls & $\begin{array}{l}\text { Vaccinated } \\
\text { patients }\end{array}$ & Controls \\
\hline $\begin{array}{l}3 \text { Months } \\
6 \text { Months } \\
12 \text { Months }\end{array}$ & $\begin{array}{l}3 / 8 \\
4 / 8 \\
4 / 7\end{array}$ & $\begin{array}{l}0 / 7 \\
2 / 7 \\
3 / 5\end{array}$ & $\begin{array}{l}2 / 8 \\
3 / 8 \\
4 / 7\end{array}$ & $\begin{array}{l}0 / 7 \\
0 / 7 \\
0 / 5\end{array}$ \\
\hline
\end{tabular}

The striking differences lay in the death rates at one year and in the early widespread recurrences in three vaccinated patients at three months. To have reversed the trend and obtained a result in favour of vaccination would have required at least six consecutive deaths in the control group and none in the vaccinated group. In addition it would have required early recurrences that were unusually widespread in the control group. We did not think it justifiable to wait and see if these unlikely trends were in fact observed.

Patients with extensive lymph node involvement or who were PPD-negative tended to fare badly: six of the seven patients who had more than four lymph nodes containing tumour deposits developed recurrences and three of these seven were also PPD-negative. None of the other measures of immune responsiveness could, however, be correlated with outcome. Three patients with extensive node disease were in the control group, while four were vaccinated, and two controls and four patients who were vaccinated were PPD-negative (table I).

Apart from transient fever vaccination was generally well tolerated, although four patients developed persistent discharging sinuses at vaccination sites. One patient developed raised alkaline phosphatase and transaminase concentrations, and she probably had a granulomatous hepatitis, since the abnormalities disappeared after treatment with isoniazid, despite normal findings on liver biopsy.

\section{Discussion}

It is difficult to determine the effect of treatment in malignant melanoma because the course of the disease is so variable. Nevertheless, the tumour recurrences in our vaccinated patients were so widespread and so early compared with those in our controls that tumour enhancement seemed a possibility. The results in our controls were broadly similar to those obtained in patients given conventional treatment elsewhere, ${ }^{1}$ but reasons for possible promotion of tumour growth in the vaccinated patients are difficult to find. The tumour vaccine we used contained cells that had been subjected to a lethal dose of radiation (15000 rads). Furthermore, similar doses of radiation have proved effective in producing vaccines that will enhance host resistance to transplantable tumours in animals. ${ }^{9}$ Comparison of control and vaccinated patients showed that they were broadly similar in age, sex, and extent of disease, so simple clinical differences between the groups were unlikely to have affected the outcome.

Conceivably differences in timing are critical in administering immunotherapeutic regimens, but this theoretical concept needs justification. Available observations outside our trial which suggest benefit have been either uncontrolled ${ }^{1011}$ or unran- 
domised, ${ }^{5}$ and our results suggest that claims of benefit based on such trials should not be readily accepted.

We thank Mr J Ransom for technical help, and Dr S Variend for reviewing the tumour histology in the patients studied.

\section{References}

${ }^{1}$ Lane, N, Lattes, R, and Malm, J, Cancer, 1958, 11, 1025.
${ }^{2}$ Hamilton-Fairley, G, British Medical fournal, 1970, 4, 483.

3 British Medical fournal, 1976, 2, 831.

${ }^{4}$ Morton, D L, et al, Surgery, 1970, 68, 158.

${ }^{5}$ Eilber, F R, et al, New England Fournal of Medicine, 1976, 294, 237.

${ }^{6}$ Gutterman, J U, et al, New England Fournal of Medicine, 1974, 291, 592.

' Ikonopisov, R L, et al, British Medical fournal, 1970, 2, 752.

${ }^{8}$ Bast, R C, et al, New England fournal of Medicine, 1974, 290, 1413.

${ }^{9}$ Baldwin, R W, and Pimm, M V, British fournal of Cancer, 1973, 28, 281.

${ }_{10}$ Ikonopisov, R L, Tumori, 1972, 58, 121.

${ }^{11}$ Grant, R M, et al, Lancet, 1974, 2, 1096.

(Accepted 23 December 1976)

\title{
CONDENSED REPORT
}

\section{Acquired myopia in 11-year-old children}

\author{
CATHERINE S PECKHAM, PETER A GARDINER, HARVEY GOLDSTEIN
}

evidence that intellectual gain precedes the appearance of myopia and has suggested that the gene responsible for shortsightedness may have conferred an evolutionary advantage through its association with intelligence.

The National Child Development Study has presented us with an opportunity to identify from a nationally representative sample of children those who had acquired myopia by the age of 11 years and to examine their social background, growth, and educational performance at 7 and 11 years of age. This group was compared with children who had normal unaided visual acuity of $6 / 6$ or better in both eyes. from non-manual families than in those from manual families. Short-sighted children were more likely to come from small families and to be of higher birth order than children with normal vision, and these associations held within each social class.

At 11 years myopic children showed striking advantages in educational performance over their normal-sighted peers, as judged by tests of reading, arithmetic, and general ability. After adjustments had been made for social background, this age gain still amounted to over one year. Findings obtained at 7 years of age showed that superior educational attainments were already apparent before the onset of myopia. Children with myopia read in their leisure time more often than normally sighted children, but despite the visual impairment, they participated in outdoor sports as often as other children.

\section{Introduction}

Myopia, or short sight, is an important and common cause of visual impairment which is usually acquired and nearly always progressive. ${ }^{1}$ It rarely occurs before the age of 6 years, and new cases appear throughout childhood and adolescence, particularly between the ages of 7 and 12 . Recently Karlsson ${ }^{2}$ has produced

National Children's Bureau, London EC1V 7QE

CATHERINE S PECKHAM, MD, MFCM, senior medical research officer PETER A GARDINER, MD, DOMS, research fellow in ophthalmology, Guy's Hospital, London

HARVEY GOLDSTEIN, BSC, professor of statistical methods, University of London Institute of Education, London WC1H OAL

\section{Methods}

The National Child Development Study, conducted by the National Children's Bureau, is a longitudinal survey of all children living in England, Scotland, and Wales who were born in one week in March $1958 .^{3}$ This originated from the 17000 children in the National Birthday Trust Fund's Perinatal Mortality Survey. ${ }^{4}$ Medical, social, and educational data were obtained at 7 and 11 years of age from four main sources. Parents were interviewed by health visitors in the home; community paediatricians carried out medical examinations; teachers filled in questionnaires at school; and the child completed a number of tests, and, at 11 years only, a questionnaire.

The educational tests used at 11 years included a reading comprehension test, which was developed to parallel the Watts-Vernon test, ${ }^{5}$ an arithmetic test, and a test of general ability. These tests were constructed and standardised for 11 year olds by the National Foundation for Educational Research. An estimate of the average changes in test scores with age was available and the raw test scores were divided by this estimate and adjusted to give a mean of 11 years, so that the average differences could be expressed in terms of age equivalent changes. These values must not be interpreted too rigidly since they are specific to the tests and are applicable only within a limited range of ages. ${ }^{6}$

At 7 years the Southgate reading test and a specially designed problem arithmetic test were used, with similar age-related scales. ${ }^{3}$

\section{ASSESSMENT OF VISUAL ACUITY}

At both medical examinations distant visual acuity was tested using the Snellen chart of block capitals under standard conditions. Each eye was tested separately. When glasses were worn testing was carried out first without and then with the aid of glasses. At the 11-year examination near vision was also tested using a card especially designed for the study by Sheridan and Gardiner. ${ }^{\text {? }}$ 